\title{
Dietary Saturated Fat: Facts and Fallacies
}

\author{
${ }^{1}$ Sandeep Kumar, ${ }^{2}$ Niket Verma, ${ }^{3}$ Nalin K Mahesh, ${ }^{4}$ Narendra Kotwal, ${ }^{5}$ Muthukrishnan Jayaraman, ${ }^{6}$ Sanjeev Kumar, \\ ${ }^{7}$ Ashwin Mahesh
}

\section{ABSTRACT}

Aim: This review aims to reassess the role of saturated fatty acids (SFAs) in the diet in light of recent evidence which shows that consumption of SFAs is probably safer than previously thought.

Background: SFAs are an integral component of dietary fat. The association between SFAs and non-communicable diseases has been studied and debated for decades. The belief about the adverse effects of SFAs has been challenged by some recent studies and meta-analyses which depicted that consumption of carbohydrates rather than SFAs is possibly the main culprit for the causation of noncommunicable diseases. This has raised the need for reassessment of dietary guidelines for saturated fat consumption.

Review results: There is no consensus on incriminating SFAs for ill health. Some studies have shown adverse effects of SFA on health whereas other studies have failed to do so. Recent analysis suggests that there is no association of SFA consumption with an increased incidence of non-communicable diseases. However, consumption of trans fats, especially the industrially derived ones, is associated with the adverse outcomes.

Conclusion: Recent advanced statistical techniques, large scale meta-analysis and interventional trials on specific SFAs on disease outcome have been changing the concept and understanding over the last few years. It has well been understood that replacing carbohydrates for SFAs has been associated with more adverse outcome. Recent systematic reviews and meta-analyses have disproved the older concept about the deleterious effects of SFAs.

Clinical significance: Consumption of SFAs is probably safe. The intake of industrialized fats, trans fats, and red meat should be limited.

Keywords: Dietary fats, Fatty acids, Noncommunicable diseases.

How to cite this article: Kumar S, Verma N, Mahesh NK, Kotwal N, Jayaraman M, Kumar S, Mahesh A. Dietary Saturated Fat: Facts and Fallacies. J Med Acad, 2018;1(2):102-108.

\footnotetext{
${ }^{1,2}$ Assistant Professor, ${ }^{3-5}$ Professor, ${ }^{6}$ Senior Registrar, ${ }^{7}$ Research Assistant

1-3,5,7 Department of General Medicine, Army College of Medical Sciences, New Delhi, India

${ }^{4}$ Department of General Medicine, Army Hospital Research and Referral, New Delhi, India

${ }^{6}$ Department of Family Medicine, Armed Forces Clinic, New Delhi, India
}

Corresponding Author: Niket Verma, Assistant Professor, Department of General Medicine, Army College of Medical Sciences, New Delhi, India, e-mail: drniketverma@gmail.com

\section{Source of support: Nil \\ Conflict of interest: None}

\section{INTRODUCTION}

Fats act as precursors of many essential compounds required by the body. In common term, the oils used for cooking (liquid) and solid fats (butter, ghee, etc.) are together referred to as fats. These add taste, texture, flavor to food and make it palatable. Fats serve as rich sources of energy (1 fat = 9 Kcals) and also provide a supply of essential fatty acids (linoleic n-6 and alpha-linolenic n-3). Fatty acids (FAs) are the building blocks all dietary fats. They are chiefly of two types; saturated fatty acids (SFAs) and unsaturated (monounsaturated fatty acids (MUFAs) and polyunsaturated fatty acids (PUFAs). Tocopherols, tocotrienols, sterols, etc. are minor components found in dietary fats. They add natural flavor to fats/oils. They also act as antioxidants and prevent rancidity. They have been reported to lower blood cholesterol level. The process of refining of oils alters the content of minor elements. Saturated fatty acids are an integral component of dietary fat. It has long been leveled to have a deleterious effect on health if consumed in excess. Several intervention studies, from the past, which had concluded in favor of restricting dietary SFA had its fallacies. The association between SFA and non-communicable diseases like diabetes, hypertension and cardiovascular diseases has been studied and debated for the past few decades. The belief about the adverse effects of SFA has been challenged by some recent studies and meta-analysis which depicted that consumption of carbohydrates rather than SFA is possibly the main culprit for the causation of noncommunicable diseases. This has raised the need for reassessment of dietary guidelines for saturated fat consumption.

\section{Important Physiological Roles of Fat}

Fats are an important source of energy. However, they also play many other physiological roles as depicted in Table 1. Table 2 enumerates various common dietary sources of FA.

\section{TYPES OF SFAs AS PER CARBON CHAIN LENGTH}

SFAs can be classified as short-chain (SC), mediumchain (MC) and long-chain (LC). A combination of 
Table 1: Various physiological roles of fat

\begin{tabular}{ll}
\hline Physiological role & Mechanism \\
\hline Energy & Chief source of energy $1 \mathrm{~g}$ fat $\cong 9$ kcal \\
Structural component & Constituent cell membrane and various body fluids along with proteins \\
Vitamin metabolism & $\begin{array}{l}\text { absorption of the four fat-soluble vitamins (A, D, E, and K) } \\
\text { Hunger control }\end{array}$ \\
Induces satiety \\
Precursors & (EFA) namely, linoleic (LA n-6) and alphalinolenic (ALA n-3) acids undergo various metabolism to produce \\
& various biologically-active compounds like prostaglandins, etc. \\
\hline
\end{tabular}

Table 2: Dietary sources of various fats

\begin{tabular}{|c|c|c|c|c|}
\hline $\begin{array}{l}\text { Saturated } \\
\text { (SFAs) }\end{array}$ & Monounsaturated & Polyunsaturated & & \\
\hline \multirow{5}{*}{$\begin{array}{l}\text { Ghee } \\
\text { Coconut oil } \\
\text { Palm oil } \\
\text { Vanaspati } \\
\text { Butter }\end{array}$} & \multirow{5}{*}{$\begin{array}{l}\text { Groundnut, } \\
\text { Sesame, } \\
\text { Red palm and } \\
\text { Rice bran Oil }\end{array}$} & Linoleic acid $(n-6)$ & & a-linolenic $(n-3)$ \\
\hline & & Low & Red palm and & \multirow{4}{*}{$\begin{array}{l}\text { Rapeseed, } \\
\text { Mustard and } \\
\text { Soyabean oil }\end{array}$} \\
\hline & & & Palmolein Uil & \\
\hline & & Medium & $\begin{array}{l}\text { Groundnut, Ricebran } \\
\text { and Sesame Oil }\end{array}$ & \\
\hline & & High & $\begin{array}{l}\text { Soyabean, safflower, } \\
\text { Sunflower oil, and Corn Oil }\end{array}$ & \\
\hline
\end{tabular}

these, along with monounsaturated fatty acids (MUFA) and polyunsaturated fatty acids (PUFA) are found in dairy fat.

\section{Saturated Fatty Acids in Commonly Consumed Foods and Oils}

Indian food is cooked mainly with a fat medium like mustard oil, coconut oil, ghee, butter or vanaspati. Table 3 enumerates the saturated fatty acids found in commonly consumed foods and oils.

\section{Biomarkers for SFA}

There are certain biomarkers in the blood by which we can predict the presence or absence of fatty acids. Pentadecanoic (15:0) and margaric (17:0) acid, are not synthesized in humans. They are valid biomarkers for dairy or lamb, beef, venison, and fatty fish intake. ${ }^{1,2}$ The dietary palmitic acid (16:0) intake can be assessed by measuring the ratio of $16: 1$ to $16: 0 .^{3}$

\section{SFAs, Trans-Fats (TFA) and Adverse Health Outcomes}

SFA resembles TFAs in molecular geometry. Transfats are found in partially hydrogenated vegetable fats, junk foods, ruminant milk, and meats. They are attributed to adverse metabolic effects and have been associated with obesity, insulin resistance, endothelial inflammation, and atherosclerosis. ${ }^{4}$

TFAs chiefly have the following effects on lipid metabolism:

- Lower high-density lipoprotein (HDL) and lowdensity lipoprotein (LDL) cholesterol particle size

- Increase total cholesterol (TC): HDL cholesterol ratio

- Increase apolipoprotein B:apolipoprotein A1 ratio
Table 3: SFA in commonly consumed foods and oils

\begin{tabular}{ll}
\hline Source & Chief content \\
\hline Coconut oil & Lauric acid (12:0) \\
Palm oil & Palmitic acid (16:0) and Oleic \\
& acid (18:1n-9) \\
Dietary SFA, animal fat and & Palmitic acid (16:0) and \\
varying plant oils & stearic acid (18:0) \\
\hline
\end{tabular}

- Increase triglycerides (TGs) and Lipoprotein (a) levels. $^{4}$

\section{Pathophysiological Effects of SFA}

- Effects at the cellular level (Flowchart 1): SFAs cause proinflammatory gene expression in adipose tissues and accumulation of diacylglycerol and ceramide which in turn activates various intermediates and induce inflammatory genes and cascade of apoptosis. SFAs acting as ligands activate toll-like receptors $4 / 2$ which further induces inflammation and causes insulin resistance. ${ }^{5-8}$

- Effect on circulating lipid metabolism (Flowchart 2): SFAs act through stearoyl-CoA desaturase-1 (SCD1) by increasing the enzyme's activity which, in turn, decreases fat accumulation in liver but increases plasma VLDLs. The atherosclerotic effect is through the formation of foam cells via synthesis of cholesteryl oleate from SCD1. 910

- Effect of SFA on Insulin resistance, pancreatic dysfunction and cardio-metabolic health (Flowchart 3): SFAs can cause excessive accumulation of intracellular triglycerides (TGs) in pancreatic cells. Subsequent oxidation of TGs causes cellular injury. Increased TGs in pancreatic beta cells cause increased nitric oxide ceramide synthesis which in turn increases endoplasmic reticulum stress. Due to a change in redox potential of cells, 
Flowchart 1: Pathophysiological effects of SFAs at cellular level

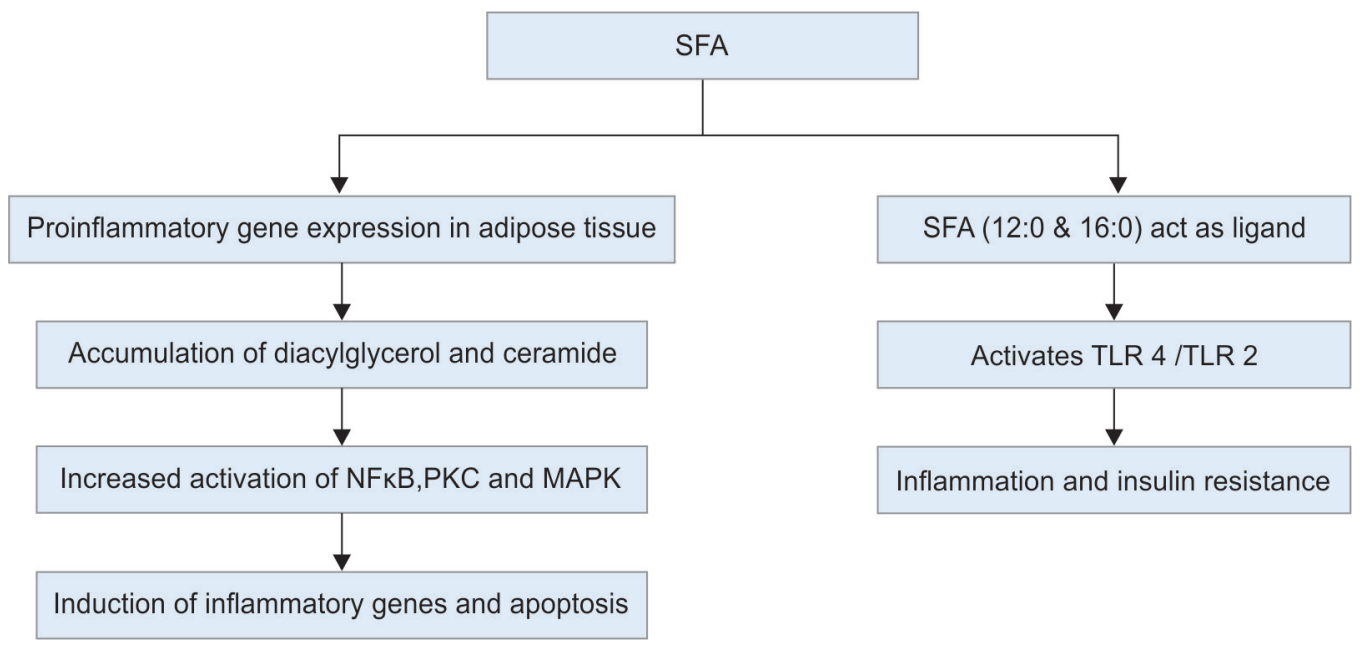

Flowchart 2: Pathophysiological effects of SFAs on circulating lipid metabolism

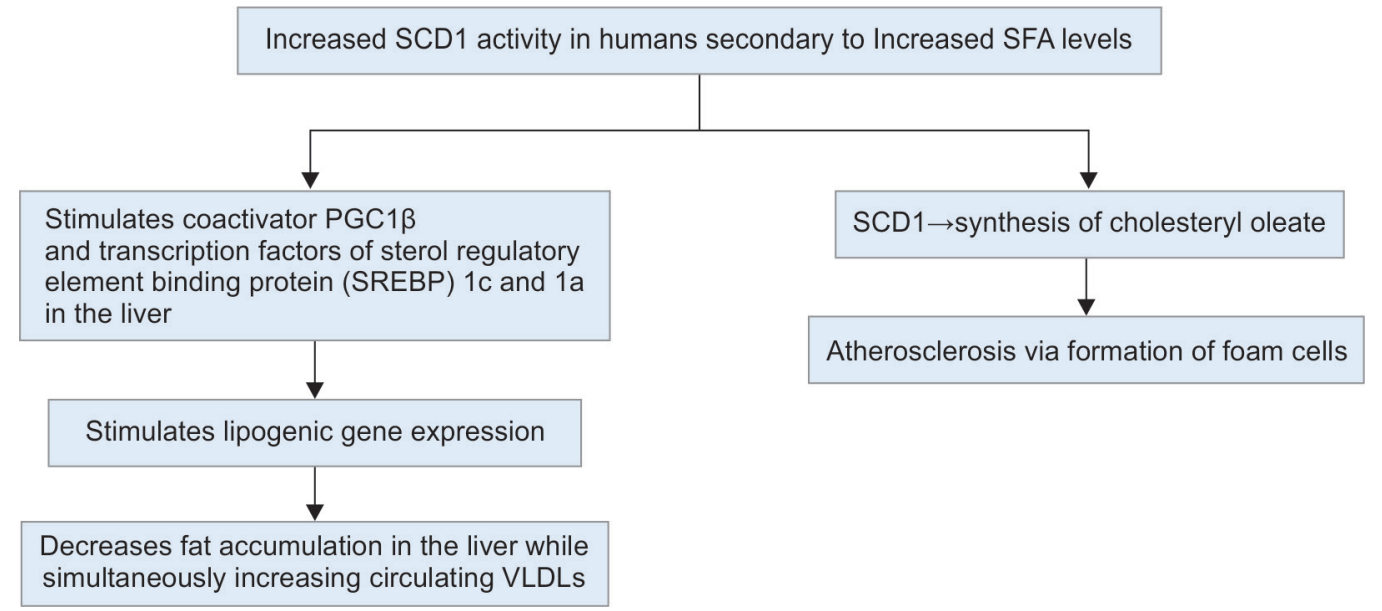

Flowchart 3: Effect of SFAs on insulin resistance and pancreatic dysfunction

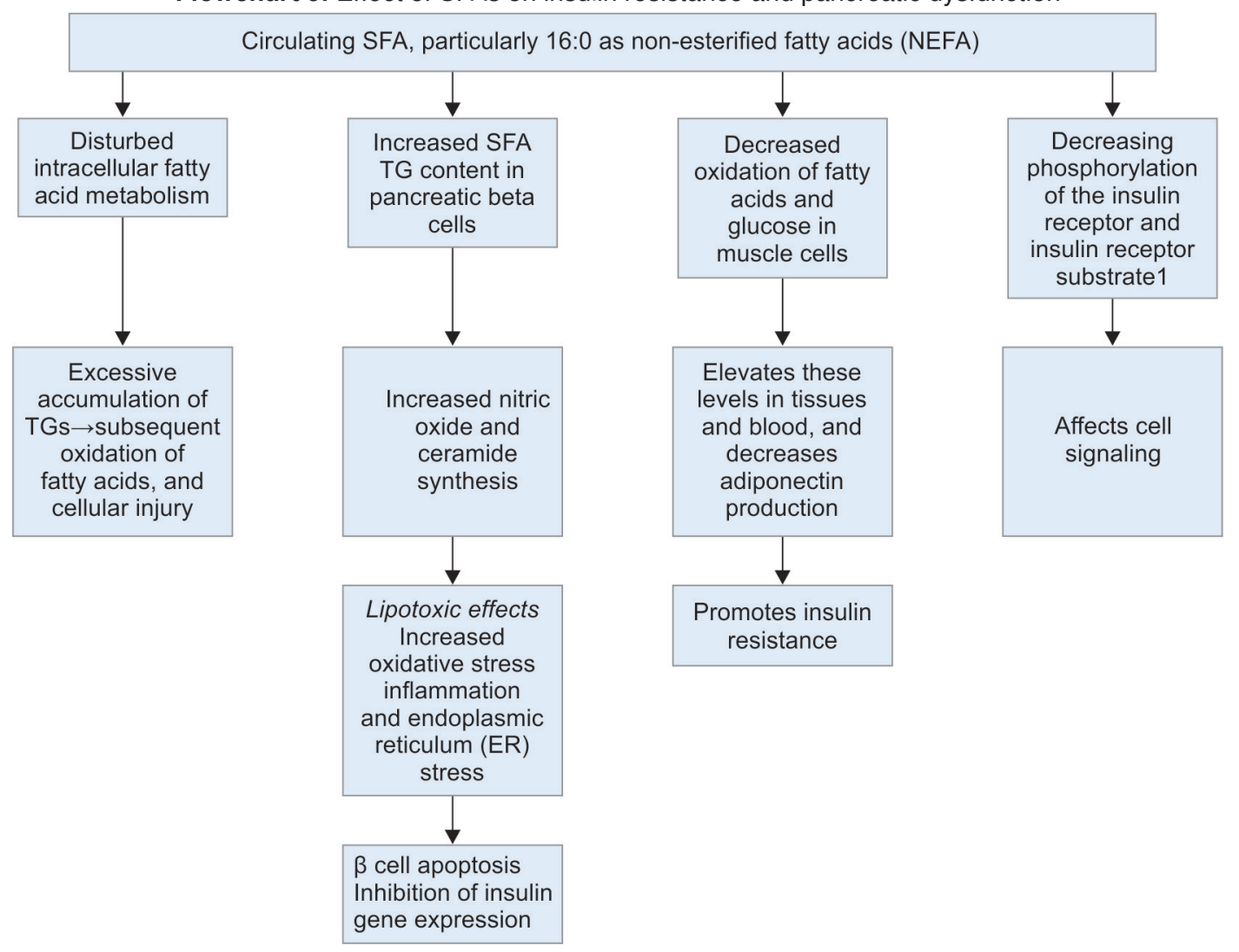


Table 4: Effect of SFA's on cardiometabolic health

\begin{tabular}{|c|c|c|c|}
\hline \multirow[b]{2}{*}{ Physiological role } & \multicolumn{3}{|c|}{ Types of SFAs } \\
\hline & Short chain SFAs & Medium-chain SFA & Long chain SFA \\
\hline Metabolic effects & $\begin{array}{l}2: 0 \text { have antimicrobial properties } \\
\text { and prevention of cancer } \\
\text { and inflammation of the large } \\
\text { intestine }{ }^{15,16}\end{array}$ & Reduce adiposity ${ }^{17,18}$ & $\begin{array}{l}\text { Dietary SFAs are a mostly long chain } \\
14: 0-18: 014: 0 \text { and } 16: 0 \text { may have various } \\
\text { regulatory functions in the cell via protein } \\
\text { fatty acid acetylation }^{19}\end{array}$ \\
\hline $\begin{array}{l}\text { Cardiovascular risk } \\
\text { factors }\end{array}$ & & & $\begin{array}{l}\text { Increase in total cholesterol and LDL-C, } \\
\text { except 18:0, which is neutral. Long-chain } \\
\text { SFA lauric acid (12:0) is the most potent SFA } \\
\text { for raising cholesterol but also reduces the } \\
\text { total cholesterol:HDL-C ratio. Some studies } \\
\text { suggest an atherogenic and prothrombotic } \\
\text { effect of } 18: 0 \text {, but not consistently. }{ }^{19}\end{array}$ \\
\hline $\begin{array}{l}\text { Cardiovascular } \\
\text { disease }\end{array}$ & \multicolumn{3}{|c|}{$\begin{array}{l}\text { Epidemiological studies have not proven overall SFA consumption to be related to increased cardiovascular } \\
\text { disease (CVD). SFA replaced with polyunsaturated fatty acids decreased cardiovascular disease outcome } \\
\text { in some studies. Increased risk of coronary heart disease was observed in some studies for } 12: 0,14: 0,16: 0 \\
\text { and } 18: 0 .{ }^{20-22}\end{array}$} \\
\hline $\begin{array}{l}\text { Insulin resistance } \\
\text { and diabetes }\end{array}$ & No proven role & No proven role & $\begin{array}{l}\beta \text {-cell function in vitro are negatively affected } \\
\text { by } 16: 0 \text { and } 14: 0 \text { and } 15: 0 \text { is inversely } \\
\text { associated with diabetes along with other risk } \\
\text { factors. }{ }^{23,24}\end{array}$ \\
\hline $\begin{array}{l}\text { Cardiometabolic } \\
\text { risk with dairy food }\end{array}$ & \multicolumn{3}{|c|}{$\begin{array}{l}\text { SFAs especially } 15: 0 \text { and 17:0 LDL-Cholesterol, increases Cardio-Vascular Disease risk. Milk fat } \\
\text { biomarkers have been inversely associated with insulin resistance and risk for myocardial infarction. }{ }^{25,26}\end{array}$} \\
\hline
\end{tabular}

Table 5: Various beneficial effects of SFA

\begin{tabular}{|c|c|c|}
\hline Types of SFA & Example & Effects \\
\hline \multirow[t]{3}{*}{ Short chain fatty acids up to 6 carbons } & Propionic acid (3:0) & $\begin{array}{l}\text { Immunosuppressive actions } \\
\text { Beneficial in obesity and type } 2 \text { diabetes }{ }^{15}\end{array}$ \\
\hline & Butyric acid $(4: 0)$ & Action on Gene regulation \\
\hline & (Found in bovine milk at $2-5 \mathrm{wt} \%$ ) & $\begin{array}{l}\text { Protective in intestinal inflammation and colon } \\
\text { cancer }^{16}\end{array}$ \\
\hline \multirow[t]{4}{*}{ Medium chain fatty acid 7-12 Carbons } & Caprylic (8:0) and Capric (10:0) acid & Favorable in obesity ${ }^{17}$ \\
\hline & Lauric acid & Appropriate in malabsorptive states. \\
\hline & & Laxative effect \\
\hline & & Helps in weight loss ${ }^{18}$ \\
\hline \multirow[t]{6}{*}{ Long chain fatty acids $>12$ carbons } & Monolaurin from 12:0 & Antimicrobial effects \\
\hline & & Protective effects against Streptococci ${ }^{27}$ \\
\hline & & Topical protection against HIV in primates ${ }^{28}$ \\
\hline & & $\begin{array}{l}\text { Protection to the gut mucosal surfaces of the } \\
\text { infant. }^{29}\end{array}$ \\
\hline & Dietary myristic acid (14:0) & $\begin{array}{l}\text { Protein fatty acid acetylation various } \\
\text { regulatory functions in the cell } \\
\text { (myristoylation) }^{19}\end{array}$ \\
\hline & Palmitoylation 16:0 & $\begin{array}{l}\text { Membrane interactions and signal } \\
\text { transduction. }{ }^{19}\end{array}$ \\
\hline
\end{tabular}

there is increased cell death. SFAs can cause decreased production of adiponectin and also decreased phosphorylation of insulin receptors and its substrate-1, which in turn promote insulin resistance. ${ }^{11-14}$

- Effects of SFAs on cardiometabolic health are enumerated in Table 4.

- Various beneficial effects of SFAs: Saturated fatty acids are also reported to have many beneficial effects including protection against intestinal inflammation and promotion of weight loss. The beneficial effects are outlined in Table 5.

\section{SFA Consumption and the Indian Diet}

The cooking media used in Indian diet has a wide range of visible and invisible fat. Table 6 describes various constituents of common cooking media, calorie content and recommended daily allowance (RDA). ${ }^{30}$

\section{ICMR Recommendations (2011) on Fat Consumption}

Indian Council for medical research dietary guidelines (2nd edition 2011) recommended that saturated fats 
Table 6: Constituents, calorie content and RDA of commonly used cooking media

\begin{tabular}{|c|c|c|}
\hline Types of fat & \multicolumn{2}{|l|}{ Visible fat } \\
\hline \multirow[t]{2}{*}{ Source } & \multicolumn{2}{|l|}{ Ghee } \\
\hline & Butter & Vanaspati \\
\hline Calorie content & \multicolumn{2}{|c|}{$20-30 \%$ of total calories in the diet should co } \\
\hline RDA & \multicolumn{2}{|c|}{$\begin{array}{l}\text { Up to } 50 \mathrm{~g} \text { per person per day depending on } \\
\text { physical activity }\end{array}$} \\
\hline \multicolumn{2}{|c|}{ Physiological state } & Requirement \\
\hline \multicolumn{2}{|c|}{ Sedentary lifestyle } & $25 \mathrm{~g}$ of visible fat \\
\hline \multicolumn{2}{|c|}{ Hard physical work } & $30-40 \mathrm{~g}$ of visible fat \\
\hline \multicolumn{2}{|c|}{ Pregnancy and lactation } & $30 \mathrm{~g}$ \\
\hline \multicolumn{2}{|c|}{ Young children and adolescents } & $30-50$ g/day \\
\hline
\end{tabular}

should be limited to $<10 \%$ (5-6\% for those who would benefit from lowering of LDL cholesterol), and trans fats to $<1 \%$ of energy or as low as possible, primarily to reduce risk of ischemic heart disease and stroke. ${ }^{30}$ Calories from various Fatty Acids should be limited to SFA $8-10 \%$, PUFA $8-10 \%$, MUFA $8-10 \% .{ }^{30}$ The diet should contain more than one type of cooking oil to provide a variety of SFAs, PUFA, and MUFA (Table 7). Regular consumption of oils and foods rich in alpha-linolenic (n-3) is to be ensured. Fish provides preformed long-chain n-3 PUFA. Nuts and legumes contain a good proportion of alpha-linolenic (n-3) acid, protein, fiber, vitamins, and minerals. A part of visible fat intake can be substituted by nuts and legumes. Certain other useful substances are found in plant oils such as sterols, tocopherols (vitamin E), lignans (sesame oil), oryzanol (rice bran oil), carotenoids. These are helpful in reducing cholesterol and also act as anti-oxidant. Hydrogenation of unsaturated fatty acids converts them to SFA, and the isomers are called trans-fat. Vanaspati is hydrogenated fat. It is used as a substitute for other cooking oils, ghee or butter. It keeps the foods prepared by it fresh for a longer time because of resistance to oxidation. Consumption of vanaspati also increases the intake of trans fatty acids which increases the risk of heart disease. The probable safe limit of consumption is less than $1 \%$ of total energy intake. ${ }^{30}$

\section{VARIOUS STUDIES ON SFAS}

Researchers have conducted various studies in the past to study the role of SFAs on health; however, there is no consensus on incriminating SFAs for ill health. Some studies have shown adverse effects of SFAs on health whereas other studies have failed to do so (Table 8).

In a recent systematic review and meta-analysis of observational studies Russell J de Souza et al. studied the associations of communicable diseases outcome Invisible fat

Integral components of various foods. Average content-15 $\mathrm{g}$ in rural food, $30 \mathrm{~g}$ in urban food cereals contain $2-3 \%$ 
communicable diseases. This inference was based on the outcome of several prospective interventional trials which were either short duration studies or had many methodological or heterogeneous bias and limitations. None of the trials compared the effect of polyunsaturated fat on cardiovascular disease (CVD) and/or coronary heart disease (CHD) if replaced in place of saturated fat. Therefore, it is impossible to predict the solo effect of saturated fats on CVD/CHD. Recent advanced statistical techniques, large scale meta-analysis and interventional trials on specific SFAs on disease outcome have been changing the concept and understanding over the last few years. It has well been understood that replacing carbohydrates for SFAs has been associated with more adverse outcome. Recent systematic reviews and meta-analyses have disproved the older concept about SFAs. Therefore, consumption of SFAs is probably safe. The intake of industrialized fats, trans fats, and red meat should be limited. However, before coming to a definite conclusion and changing dietary recommendations, the authors suggest that long term, large populationbased prospective interventional cohort studies should be contemplated to study the possible effect of each different saturated fat on CHD/CVD with CVD as the endpoint and effect of dietary control of SFAs with plasma cholesterol level as the endpoint.

\section{REFERENCES}

1. Hodson L, Skeaff CM, Fielding BA. Fatty acid composition of adipose tissue and blood in humans and its use as a biomarker of dietary intake. Progress in lipid research. 2008;47(5):348-380.

2. Baylin A, Kabagambe EK, Siles X, Campos H. Adipose tissue biomarkers of fatty acid intake. The American journal of clinical nutrition. 2002;76(4):750-757.

3. Risérus U, Ärnlöv J, Berglund L. Long-Term Predictors of Insulin Resistance Role of lifestyle and metabolic factors in middle-aged men. Diabetes care. 2007;30(11):2928-2933.

4. Micha R, Mozaffarian D. Trans fatty acids: effects on cardiometabolic health and implications for policy. Prostaglandins, Leukotrienes and Essential Fatty Acids. 2008;79(3):147-152.

5. van Dijk SJ, Feskens EJ, Bos MB, Hoelen DW, Heijligenberg R, Bromhaar MG, et al. A saturated fatty acid-rich diet induces an obesity-linked proinflammatory gene expression profile in adipose tissue of subjects at risk of metabolic syndrome. The American journal of clinical nutrition. 2009;90(6):1656-1664.

6. Siskind LJ. Mitochondrial ceramide and the induction of apoptosis. Journal of bioenergetics and biomembranes. 2005;37(3):143-153.

7. Stiban J, Fistere D, Colombini M. Dihydroceramide hinders ceramide channel formation: implications on apoptosis. Apoptosis. 2006;11(5):773-780.

8. Kim JK. Fat uses a TOLL-road to connect inflammation and diabetes. Cell metabolism. 2006;4(6):417-419.

9. Degirolamo C, Shelness GS, Rudel LL. LDL cholesteryl oleate as a predictor for atherosclerosis: evidence from human and animal studies on dietary fat. Journal of lipid research. 2009;50(Supplement):S434-S439.

10. Lin J, Yang R, Tarr PT, Wu P-H, Handschin C, Li S, et al. Hyperlipidemic effects of dietary saturated fats mediated through PGC-1 $\beta$ coactivation of SREBP. Cell. 2005;120(2): 261-273.

11. Reynoso R, Salgado LM, Calderón V. High levels of palmitic acid lead to insulin resistance due to changes in the level of phosphorylation of the insulin receptor and insulin receptor substrate-1. Vascular Biochemistry: Springer; 2003. p. 155-162.

12. Zeitler PS, Nadeau KJ. Insulin resistance: childhood precursors and adult disease: Springer Science and Business Media; 2008.

13. Poitout V, Robertson RP. Glucolipotoxicity: fuel excess and $\beta$-cell dysfunction. Endocrine reviews. 2008;29(3):351-366.

14. Manco M, Calvani M, Mingrone G. Effects of dietary fatty acids on insulin sensitivity and secretion. Diabetes, Obesity and Metabolism. 2004;6(6):402-413.

15. Sa'ad H, Peppelenbosch MP, Roelofsen H, Vonk RJ, Venema K. Biological effects of propionic acid in humans; metabolism, potential applications and underlying mechanisms. Biochimica et Biophysica Acta (BBA)-Molecular and Cell Biology of Lipids. 2010;1801(11):1175-1183.

16. Sengupta S, Muir JG, Gibson PR. Does butyrate protect from colorectal cancer? Journal of gastroenterology and hepatology. 2006;21(1):209-218.

17. Tsuji H, Kasai M, Takeuchi H, Nakamura M, Okazaki M, Kondo K. Dietary medium-chain triacylglycerols suppress accumulation of body fat in a double-blind, controlled trial in healthy men and women. The Journal of nutrition. 2001;131(11):2853-2859.

18. Waqar AB, Koike T, Yu Y, Inoue T, Aoki T, Liu E, et al. Highfat diet without excess calories induces metabolic disorders and enhances atherosclerosis in rabbits. Atherosclerosis. 2010;213(1):148-155.

19. Legrand P, Rioux V. The complex and important cellular and metabolic functions of saturated fatty acids. Lipids. 2010;45(10):941-946.

20. Micha R, Mozaffarian D. Saturated fat and cardiometabolic risk factors, coronary heart disease, stroke, and diabetes: a fresh look at the evidence. Lipids. 2010;45(10):893-905.

21. Mente A, de Koning L, Shannon HS, Anand SS. A systematic review of the evidence supporting a causal link between dietary factors and coronary heart disease. Archives of internal medicine. 2009;169(7):659-669.

22. Siri-Tarino PW, Sun Q, Hu FB, Krauss RM. Meta-analysis of prospective cohort studies evaluating the association of saturated fat with cardiovascular disease. The American journal of clinical nutrition. 2010:ajcn. 27725.

23. Summers L, Fielding B, Bradshaw H, Ilic V, Beysen C, Clark M, et al. Substituting dietary saturated fat with polyunsaturated fat changes abdominal fat distribution and improves insulin sensitivity. Diabetologia. 2002;45(3):369-377.

24. Schwab US, Niskanen LK, Maliranta HM, Savolainen MJ, Kesaniemi YA, Uusitupa MI. Lauric and palmitic acid-enriched diets have minimal impact on serum lipid and lipoprotein concentrations and glucose metabolism in healthy young women. Journal of Nutrition. 1995;125(3):466-473.

25. Mozaffarian D, Cao H, King IB, Lemaitre RN, Song X, Siscovick DS, et al. Trans-palmitoleic acid, metabolic risk factors, and new-onset diabetes in US adults: a cohort study. Annals of internal medicine. 2010;153(12):790-799. 
26. German JB, Gibson RA, Krauss RM, Nestel P, Lamarche B, Van Staveren WA, et al. A reappraisal of the impact of dairy foods and milk fat on cardiovascular disease risk. European journal of nutrition. 2009;48(4):191-203.

27. Batovska DI, Todorova T, Tsvetkova V, Najdenski HM. Antibacterial study of the medium chain fatty acids and their 1-monoglycerides: individual effects and synergistic relationships. Polish Journal of Microbiology. 2009;58(1): 43-47.

28. Li Q, Estes JD, Schlievert PM, Duan L, Brosnahan AJ, Southern PJ, et al. Glycerol monolaurate prevents mucosal SIV transmission. Nature. 2009;458(7241):1034-1038.
29. Isaacs CE. Human milk inactivates pathogens individually, additively, and synergistically. The Journal of nutrition. 2005;135(5):1286-1288.

30. Manual A. Dietary Guidelines for Indians.

31. Hoenselaar R. Saturated fat and cardiovascular disease: The discrepancy between the scientific literature and dietary advice. Nutrition. 2012;28(28(2012)):118-123.

32. de Souza RJ, Mente A, Maroleanu A, Cozma AI, Ha V, Kishibe $\mathrm{T}$, et al. Intake of saturated and trans unsaturated fatty acids and risk of all cause mortality, cardiovascular disease, and type 2 diabetes: systematic review and metaanalysis of observational studies. 2015. 